\title{
Political Economy of Sending Domestic Workers Abroad: Case Study of Indonesian Migrant Workers
}

\author{
Luqman Hakim 1 \\ Anwar Fitrianto 2,3 \\ ${ }^{1}$ Department of Public Administration, Faculty of Administrative Science, University of Brawijaya, Malang, East Java, Indonesia \\ luqmanhakim.zainuri@gmail.com \\ 2 Department of Mathematics, Faculty of Science, Universiti Putra Malaysia, Malaysia \\ ${ }^{3}$ Department of Statistics, Faculty of Mathematics and Natural Resources, Bogor Agricultural University, Indonesia
}

\section{Doi:10.5901/mjss.2015.v6n4p316}

\begin{abstract}
The aim of this paper is to describe success story of public policy of the government of Indonesia in sending Indonesian workers abroad. The policy has been started from 1970s since a new regulation related to Indonesian migrant workers has been applied in that year and continued to the recent years through improved regulations. In this article, we collected secondary data through library research and then followed by Rapid Rural Appraisal in number of villages throughout some districts in East Java such as Malang, Lumajang, Jember, Bangkalan, and Sampang districts. The result shows that, the policy has been significantly successful in two aspects, namely economics and politics. In term of economy, the remittance have revitalized rural economy especially the villages which have for such a long time become center of mobilization. At the national level, the amount of remittance has been equivalent to one third of Foreign Direct Investment (FDI) to the country.
\end{abstract}

Keywords: policy, political economy of policy, state-centered approach, remittance

\section{Introduction}

Job types are related to social and economic status. Obviously, those who are in the decision making jobs implies higher rank and enjoys a relatively better salary and respect from the social environment compared to those who are in the lower rank. Job as domestic workers can be seen as a job which in day-to-day management of the house hold posits the lowest rank within the social stratification. Technically, this job refers to house maid which in Indonesia is called Pembantu Rumah Tangga (PRT). Since the job is closely related to common work of home chores like house cleaning, cooking, washing, ironing, baby care, serving needs all family members and the likes which are usually done by female, the PRT worker is usually taken by female too. As a PRT, she usually lives in a small room in her employer's house where the family lives. Normally, the PRT starts working in early morning and lasts in late night with no regular holiday in a week.

Traditionally, Indonesian family employs one or two PRTs. Many usual activities in an Indonesian household are handed by the PRT instead of by their family members. It is quite possible that the PRT enjoys a significantly important position in the family life because of better knowledge of problems of the house better than "the boss". Nevertheless, due to relatively low rank in wage, it also implies a sub-ordinated job position with low social status even in the PRT's home country. Moreover, in a certain circumstance, the PRT has been perceived of a quasi-slave as if the PRT has no right to do anything else other than her usual job and cannot say "no" to any order or decision made by the boss as well as the family members. Under such condition, the job only strikes rank and file people who have been living for such a long time with no way out under emergency or subsistence level.

The high rate of unemployment has been one main factor to political instability of the country. Since the declaration of Indonesian independence in 1945, Indonesia, like other developing countries, has to deal with problems of political instability which implies aspects such as high rate of unemployment. Many efforts have been made by the government since the era of the first president, Soekarno. Unfortunately the efforts of combating against high rate of unemployment have never been very successful.

In the second half of 1960s, when General Soeharto took the power from Soekarno, Indonesia was fraught with severe problems emanating from such various sources as conflicts of ideology, struggling for political position, poverty, and others including the high rate of unemployment. Accordingly, during that time, the country was fraught with lack of 
food, bad nutrition, bad public health, bad sanitation, lack of education and so forth. Inflation rate at that time was about $650 \%$, price of goods were inevitably sky rocketing, no food, no job opportunities and so forth because of which people were starving, mad, hostile and political stability was low. According to Moon (1991), the life situation during that period can be described as "nasty, brutish, and short."

In the New Era of Indonesia, the period when Soeharto took over as the second president of Indonesia, he took initiative, responsibility and strives to create political stability through various means such as tight policy control over politics, economics and social life. For short term, the objective surely could be reached, although for long term, it would be contra productive. Based on the assumption that the political stability can only be achieved if the unemployment rate of can be reduced to a minimum level, there is no alternatives for any government but to find as many as possible job opportunities

In general the policy of sending domestic helper abroad represents a success story of a public policy in the village economic live. Although government capability in job creation is low and always unable to meet the need of jobs, the policy can significantly reduce the unemployment rate and the absolute poverty can also be relatively up lifted. This fact is particularly interesting to be analysed for several reasons. First, job as domestic helper is a job position which will never promise a significant change in their social life. Accordingly, acceptance of the job contradicts to moral economy of people of this group. In fact, under the spirit of "no pain, no gain" they accept the job (Manning and Sumarto, 2011). Secondly, legal protection by the government over these jobs has not been adequate. Many Indonesian workers have been punished or sentenced with no adequate legal advocacy from their own capacity nor from the government. In the absence of legal protection over the position of domestic helper especially abroad, the position of migrant workers including domestic helper is fragile towards physical suppression and/or social discrimination. The question can be raised from this fact is why people of this group are in support of the policy sending workers abroad?

The aim of this paper is to analyse the relationship between government policy on sending Indonesian migrant workers as domestic helper, revival of the village economy and political stability. Data in this research are collected mainly through library research which is followed by Rapid Rural Appraisal (RRA) from mobilization centers (villages) throughout East Java such as Malang, Lumajang, Jember, Bangkalan, and Sampang districts. The way by which the data is analysed essentially follows the argument of state-centered approach in accordance with Weberian and Hintzean tradition.

\section{Literature Reviews}

\subsection{Historical Background}

Many articles have been discussing about migrant workers. Recent literatures related the migrant workers are Ruhs (2012) who discussed about protection for migrant workers, Anderson and Ruhs (2012) who discussed about employer demand for migrant labour, and Connel and Burgess who outlined some of the key issues related to migrant workers, work, public policy, and HRM. In Indonesia, sending of Indonesian workers abroad has now reached more than 1 million workers since the initiation of the program on 1970. Initially, the program was applied through Indonesian Government Regulation year 1970 under Minister of Man Power, Transmigration, and Cooperative. Implementation of the program was divided into two groups namely Inter Regions Working Program (AKAD) and Inter State Working Program (AKAN). Since then, realization of sending Indonesian workers abroad involved Private-Recruitment Agencies (PJTKI) which is responsible for marketing of the workers.

The policy of sending Indonesian workers abroad in post-colonial era was initiated by the Indonesian New Era's regime. Given the fact that there had been similar policy taken by the colonial Dutch, it did not necessarily mean that this policy represents continuation policy of the previous regime. However, the policy was not absolutely new. In the colonial era, the sending of Indonesian workers abroad had been taken by the colonial government (Dutch). In 1880 the Dutch government sent number of contract-based workers from Java and North Sumatra (Batak). They were all employed in government plantations in Suriname, South America which are also under Dutch colonies. This envoy was aimed at replacing position of African slaves which according to the law they must have been freed by July 1863 . The lack of man power due to this freedom has caused productivity of many plantations decreased drastically.

The decision of sending Javanese as the first envoy of workers was mainly due to two reasons. First is eruption of mount Merapi. Secondly, it was due to absolute poverty of the people living in Java. First group of people were transported from Java to Suriname by "SS Koningin Emma" boat on 21 May 1980 (Wibowo, 2012). They consisted of 61 man, 31 women and 2 children and made up all together 94 people. This long journey stopped over in Holland. Through 77 boats of this kind of shipping mobilization of the workers from 1890 and reached 32.986 people in 1939. 


\subsection{Corresponding Indonesian Ministry of Labour in Independence Era}

The $3^{\text {rd }}$ July may become historical date for the Indonesian Ministry of Man Power during independence era. Through Government Regulation year 194, Ministry of Man Power was established under the name of Ministry of Labour. However, in its development, the New Order government was politically sensitive to the word "labour." The term has been perceived closely related to communist ideology which in Indonesia it has "dark" history. Accordingly, during the 1st to 3rd period of the New Era in Indonesia the term Ministry of Labour was no longer used and replaced by "Ministry of Man Power, Transmigration, and Cooperative".

Migrations of the Indonesian workers abroad in fact have been occurring since previous years. However, up to the late of 1960 the placement of workers has not involved the government (Setyawati, 2013). Countries of destination at that time were Malaysia and Saudi Arabia. Those who migrated to Malaysia made the trip at their own expenses. They took the risk of the trip. Unfortunately, those who migrated during the first period were illegal in the sense with no legal travel documents. The workers migrated due to traditional family ties who lived in Malaysia. Meanwhile, for Saudi Arabia, the new workers were usually brought by those who had been living in the country before the departure of workers or by those who went for pilgrimage (hajj/umroh) to Makkah.

\subsection{State-centered Approach towards Job Market of Workers}

As it had been stated the existing policy on the sending Indonesian workers abroad has been started since 1970. Since then, the sending of Indonesian workers was conducted regularly in more lawful-systematic regulation by the state. Official institutions undertaking responsibility of sending the workers has developed from time to time and starting from 2004 the policy was not only based on a "Government Regulation" but also based on law (Indonesian Law No. 39/2004) which is at higher level of constitutional order. Since then, businesses of sending Indonesian workers abroad have involved private agency although it remains under the government responsibility. Technically the license of sending the workers abroad can only be obtained through the National Board for Placement and Protection of Indonesian Overseas Workers (BNP2TKI).

In the spirit of providing better quality in placement as well as protection of the workers, in 16 April 1999 the government issued a Presidential Decision which instructs 9 related government ministries and institutions (Foreign Affair, Ministry Transportation, Worker and Transmigration, Social Welfare, National Education, Law and Advocacy, Health, Secretariat of the State, and the Police) to provide service, assistance, and legal advocacy abroad. In 2001, the BNP2TKI was banned and replaced by a new directorate, named Directorate of Socialization and Placement of Indonesian workers. Since then, coordination among the related government institutions became stronger. In 2006 the government initiated a new program called Government to Government ( $G$ to $G$ ) migrant program to new potential marketing countries such as South Korea, Taiwan and Hong Kong. In the following years this program was developed to provide nurse for hospitals as well as helper for old people.

Based on brief above historical exploration, it is clearer that mounting amount of the Indonesian workers in both colonial and independence eras were mainly due to public policy or government intervention. Given the fact of similarity in the historical background between the colonial period and independence period, there exist differences especially in terms of reasons behind the policy and the way by which the policy is conducted. Based on the nature of Dutch colonial government, there is no doubt to say that policy of sending Indonesian workers to colonial plantations in Suriname was nothing but for the sake of colonial interest.

Basically, the policy on sending Indonesian workers abroad during independence era constitutes government intervention to domestic as well as international market of workers. The Indonesian 1945 Constitution to which all laws must be based on, leads the state to pro-actively pursue common good for citizens. Accordingly, the state perceives of itself as justified to initiate something without prior approval from people representative body as parliament. Conversely, the state may not remain passive when the state perceives of society being surrounded by common bad. As it had been stated before, at the Soeharto era took over the reign Indonesia was fraught with vicious circle of shortages such as lack of food, sanitation, health, education and so on and so forth. The situation was worsened by economic problem of a very high rate of inflation up to $650 \%$, high rate of unemployment, rocketing general prices as well as horizontal political conflicts among nations as well as the military units. All of these situations have enhanced determination of the government to interfere, penetrate markets and reshape social relations.

Given the fact that the government was not capable in creating adequate job opportunity, the government sought possibility of opening up job opportunities abroad for the sake of millions of poor, low-educated and unskilled Indonesian workers. Under such a circumstance, opening up opportunity to become domestic workers was absolutely right choice. 
However, as the individual decision to take the opportunity contains high risk too. The job recruitment was more or less dependent upon people participation rather than mobilization.

\section{Data and Methodology}

Data for this research were obtained from secondary source such as database from Bank of Indonesia as well as The Agency for the Placement and Protection of Indonesian Migrant Workers (BNP2TKI). Data for emittance data from the worker's countries destination were obtain from Bank of Indonesia (2014), meanwhile the BNP2TKI provides data regarding number of Indonesian migrant workers per year for each country. In this research we use descriptive statistics in term of graphs to have some figure about the political economics of sending Indonesian workers abroad. Descriptive statistics in forms of tables, time series plot, and clustered bar charts will be employed in order to see the trend and comparisons of remittance which were sent by the Indonesian migrant workers.

\section{Empirical Findings}

Most Indonesian female migrant workers who work in unskilled employment are employed as domestic workers (81\%). Meanwhile, most male Indonesian migrant workers are employed as common workers (72\%). The last decade shows a change in the priority destination of the Indonesian workers. The top destination country for migrant workers used to be Malaysia. However, last recent years, since many problems are rising between the workers and both the government and the society, then the destination of sending migrant workers seem to have changed to Saudi Arabia. The movements of migrant workers to Saudi Arabia are slightly increased (43\%). Meanwhile, there are some decrease movements to Malaysia by $39 \%$. It means that number of Indonesian workers as domestic workers in Saudi Arabia are likely to increase because most of those who decided to get a job as migrant workers in Saudi Arabia are placed in better position. There are big numbers of Indonesian migrant workers, and based on data from surveyed households we found that $92 \%$ of them were officially selected by private recruitment agencies (PJTKI). According to them, the key motivation to look for a job overseas was financial problem where, at the same time, they want to have higher economic condition by obtaining a job with higher pay.

Inadequate infrastructure, poverty, unemployment, a complicated regulatory environment, and regional inequality are all forcing reasons for international migration. The numbers of Indonesian migrant workers have been increasing from time to time. One of the backgrounds for the increase is the growing number of illegal migrants leaving the country not through the official recruitment scheme. As a result, In South-East Asia region, Indonesia becomes the second largest migrant worker population after the Philippines. Women become the dominant group for migrant workers from Indonesia, amounting to $79 \%$. Of this amount, $59 \%$ are working in various sectors in Malaysia, and the rest are working in the Middle East.

From the surveyed data, as it has been mentioned previously, the respondents are households of Indonesian migrant workers. On average, head of household are 40 years old. We found that most of them (80\%) are married and having children. In term of education level, most of them did not have good education level since we have found that $83 \%$ of them have educated at junior high school or below. Another demographic background of the respondents which we need to discuss is occupations of the respondents (before they decided become migrant workers). We found that they work as farmers of fishermen (29\%) and as merchants (14\%). The remaining are either as housewife (26\%), unskilled worker (13\%) and unidentified. Meanwhile, with regard to their income, most of them (63\%) have low income level by which their monthly family expenditures are not more than USD 194, which is very small. But, if we look at information regarding basic need they have it reveals that are not very poor since most of them are having electricity in their house (95\%), $84 \%$ of them have colored TV, $80 \%$ of them are having gas stove, and surprisingly, $94 \%$ of them are living in their own hose (IOM, 2010).

Indonesian migrant workers have been contributing to Indonesian GDP with large amount. By having huge number of migrant workers, latest data shows that they are able to send money to their family in Indonesia amounting more than USD 316 billion from various foreign currencies. The amount of money in form of remittances are the most visible and immediately measurable gain from international migrant workers. It can boost local economies in their home town since the money they have sent reinforces power of buying goods and services. Related to this fact, unfortunately, we found that only $56 \%$ of them are having bank savings account and only $16 \%$ have Automated Teller Machine (ATM) cards. This information raises questions about the flow of the remittances. In fact, the Bank of Indonesia has record regarding this remittances which reveal that in 2009, the remittances reached USD 6.6 billion.

In light of the increasing number of deployments of Indonesian workers overseas, remittances to Indonesia have 
also increased. The largest amounts of remittance comes annually from Southeast Asian countries (ASEAN) mainly Malaysia, Middle East countries mainly Saudi Arabia, and Far Eastern countries especially Taiwan. Recent reports on remittance of the three main regional markets in Asia published by Bank Indonesia (2004), The Agency for the Placement and Protection of Indonesian Migrant Workers (BNP2TKI), and Indonesian Financial Statistics subsequently can be described as follow.

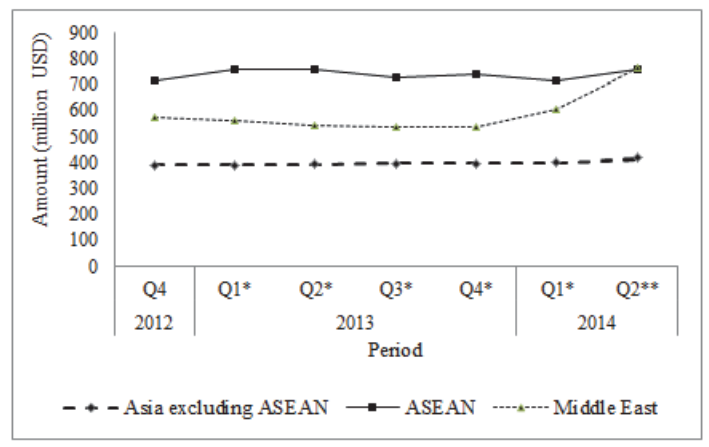

Figure 1. Remittance from Middle East, Asia (excluding ASEAN), and ASEAN countries Source: Bank Indonesia (2014)

Figure 1 describes the recent condition of remittance (within the period of 2012 - 2014) in three main regional markets which are ASEAN, Middle East and Asia excluding ASEAN. The figure shows that, in general, remittances from these three regions tend to slightly increase except Middle East which sharply increases recently. There is fluctuation in the last quarter of 2013 in ASEAN countries, but in 2014 it seems to recover and even increase. In the Middle East, the general tendency has been quite similar to ASEAN. In the Figure 1 we can also observe slight decrease of the amount of remittance in the period of 2013 and we found that the decrease was resulted from tight policy of sending abroad due to many problems in the relationship between employee and employer. However, the problems could be solved by the improvements in $\mathrm{G}$ to $\mathrm{G}$ relations. Accordingly, it can be predicted that as far as the $\mathrm{G}$ to $\mathrm{G}$ between Indonesia and recipient countries can be maintain, the market of Indonesian worker will remain open.

We will provide more detail information regarding the remittance amount in each region. We found that. in ASEAN region, Malaysia has been the most promising countries (refer to Figure 2). Meanwhile, in Middle East region, the highest amounts of remittance are from Audi Arabia, UAE, Jordan, and Qatar, respectively (Table 1). Other countries in the region give small contribution to the amount of remittance in the period of 2012 and 2014. In the intervening time, information in Table 2 indicates some optimism that in the future, Indonesian workers will develop in Far Eastern countries especially Taiwan, Hong Kong and Korea.

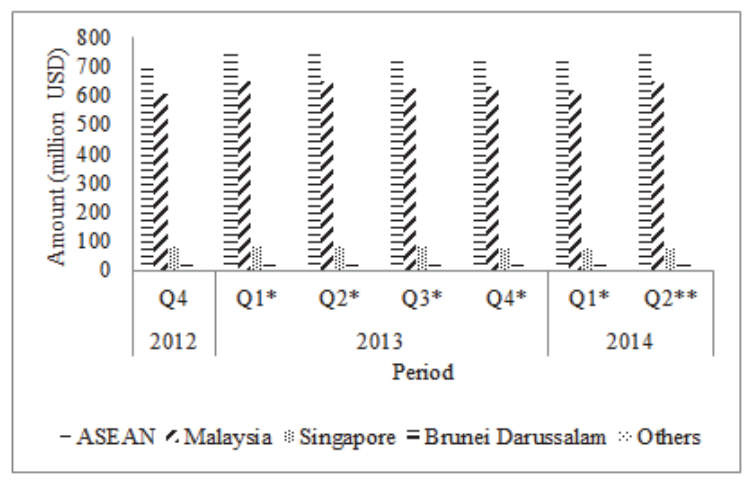

Figure 2. Remittance from ASEAN Countries within the period of 2012 and 2014

Source: Bank of Indonesia (2014)

Unfortunately, substantial quantity of the remittances sent to Indonesia by the Indonesian migrant workers are through 
informal canals. This fact creates difficulties of the government to record the real amount of the money sent from oversea. Due to that reason, Indonesian government through the Bank of Indonesia tries many methods to formalize the money flow so that the government can record it easily. The methods that the Bank of Indonesia encourages are to facilitate them to open a bank account and to facilitate classes of financial knowledge for them before departure.

Most migrant workers who are employed in the informal sector (77\%) are mainly as domestic workers. The growing motivation of taking opportunity of working in this informal sector is interesting to be analysed at least for two reasons. First, people strive to be domestic worker abroad although the job never promises any hope of change in the social status. Secondly, most of those who work abroad as domestic workers are married women with more than one child. As they have to leave home and their family, it is doubtful that economic gain earned from working as domestic worker abroad can pay the social risk for the wife, the husband, and children emanating from being separated.

Table 1. Remittance from Middle East Countries within the period of 2012 and 2014

\begin{tabular}{cccccccc}
\hline \multirow{2}{*}{ Country } & 2012 & \multicolumn{3}{c}{2013} & \multicolumn{2}{c}{2014} \\
\cline { 2 - 8 } & $\mathrm{Q} 4$ & $\mathrm{Q}^{*}$ & $\mathrm{Q}^{*}$ & $\mathrm{Q3}^{*}$ & $\mathrm{Q}^{*}$ & $\mathrm{Q}^{*}$ & $\mathrm{Q}^{* *}$ \\
\hline Saudi Arabia & 460 & 447 & 432 & 419 & 422 & 472 & 603 \\
UAE & 51 & 52 & 53 & 54 & 56 & 61 & 75 \\
Kuwait & 6 & 6 & 7 & 7 & 7 & 8 & 10 \\
Bahrain & 5 & 5 & 5 & 5 & 5 & 5 & 7 \\
Qatar & 16 & 17 & 17 & 17 & 18 & 19 & 22 \\
Oman & 7 & 7 & 7 & 8 & 8 & 10 & 14 \\
Jordan & 19 & 19 & 19 & 19 & 19 & 21 & 27 \\
Egypt & 0 & 0 & 0 & 0 & 0 & 0 & 1 \\
Cyprus & 3 & 2 & 1 & 1 & 1 & 1 & 1 \\
Others & 4 & 4 & 4 & 5 & 5 & 5 & 6 \\
\hline
\end{tabular}

Source: Bank of Indonesia (2014).

Table 2. Remittance from Asia Excluding ASEAN Countries within the period of 2012 and 2014

\begin{tabular}{cccccccc}
\hline \multirow{2}{*}{ Country } & 2012 & \multicolumn{3}{c}{2013} & \multicolumn{2}{c}{2014} \\
\cline { 2 - 8 } & Q4 & Q1 $^{*}$ & Q2 $^{*}$ & Q3 $^{*}$ & Q4 $^{*}$ & Q1 $^{*}$ & Q2 $^{* \star}$ \\
\hline Hong Kong SAR & 146 & 148 & 149 & 147 & 145 & 142 & 147 \\
Taiwan, Province of China & 155 & 156 & 160 & 161 & 162 & 158 & 176 \\
South Korea & 33 & 35 & 37 & 38 & 40 & 45 & 45 \\
Japan & 44 & 40 & 38 & 39 & 39 & 43 & 39 \\
Macau & 9 & 9 & 9 & 9 & 9 & 9 & 9 \\
Others & 1 & 1 & 2 & 2 & 2 & 2 & 2 \\
\hline
\end{tabular}

Source: Bank of Indonesia (2014).

Due to many serious problems in sending Indonesian migrant workers, the policy of sending them has been re-evaluated. As a result, in 2012 the government of Indonesia established a moratorium (suspension) of sending Indonesian workers abroad especially to Middle Eastern countries such as Saudi Arabia which have no G to G MoU with Indonesia or have no specific law of protecting migrant worker. It may refer to the temporary suspension of a law to allow a legal challenge to be carried out. The issuance of moratorium was preceded by a number of legal problems abroad arising from bad relations between the workers and employer (the family). Many of the migrant workers have been arrested by local police or authority due to crime and sentenced without proportional legal protection. Report made by Indonesian Special Task Force, there are 235 Indonesian migrant workers will be sentenced death penalty. They were dispersed in various countries as follow: Malaysia (147), Saudi Arabia (47), Republic of China (25), Iran (3), Singapore (2), and Brunei (1).

Many reports regarding abuse of Indonesian migrant workers have been received by Indonesian government and the number of abuse reported is worrying. In order to reduce this case, the government is has been employing a conscious strategy of facilitating the overseas deployment more skilled and before they depart from Indonesia. Indonesian government has been conducting various efforts such as pre-departure services to protect them before they got an employment oversea. Another effort has also been done to improve the selection like providing various necessary trainings. Despite this, reports of abuse of Indonesian workers, both by private recruitment agencies in Indonesia and 
employers abroad, are reported on a regular basis.

\section{Conclusion and Recommendation}

State-centered approach has been taken by the government of Indonesia in sending workers abroad since early 1970s has been absolutely successful. Despite a number of problems in the implementation of policy, the policy has produced positive-multi dimensional effects to the national interest. Two most apparent effects of the policy are economics and politics. In term of economy, the policy has contributed not only for survival of millions of marginal families especially in the villages but also to the national economy. The amount of remittances sent to the beneficiary families at home keeps increasing significantly. It cannot deny that the policy has significant contribution to overcome unemployment and poverty elevation. In term of politics, the policy has been successful in reducing political conflicts among people due to poverty and uneven distribution of wealth and values.

Despites some success story in term of both economic and politics, the government must pay attention to social aspects of sending migrant workers oversea. Many households have broken down. Furthermore, there are not only increasing number of crime by Indonesian migrant workers abroad, but also indications that they have been undergoing of moral decadence. It is strongly recommended that the success story in term of economy and politics to be followed by the same story in term of family life, culture, and religiosity.

\section{References}

Anderson, B. and Ruhs, M. (2012). Reliance on migrant labour: inevitability or policy choice? Journal of Poverty and Social Justice, 20(1): 23-30.

Bank of Indonesia (2014). Remitanse Tenaga Kerja Indonesia (TKI) menurut Negara Penempatan. Retrieved from http://www.bi.go.id/ seki/tabel/TABEL5_31.pdf on 12 November 2014.

Connel, J. and J. Burgess, (2009). Migrant workers, migrant work, public policy and human resource management. International Journal of Manpower, 30(5): 412 - 421.

IOM. (2010). International Migration and Migrant Workers' Remittances in Indonesia, Makati City. IOM.

Manning, C and Sumarto, S. (2011). Employment, Living Standards and Poverty in Contemporary Indonesia, Institute of Southeast Asian Studies (ISEAS), Singapore.

Moon, B. E. (1991). The political economy of basic human needs. Ithaca: Cornell University Press.

Ruhs, M. (2012). The human rights of migrant workers: Why do so few countries care. American Behavioural Scientist, 56(9): $1277-93$.

Setyawati, D. (2013). Assets or commodities? Comparing regulations of placement and protection of migrant workers in Indonesia and the Philippines. Austrian Journal of South-East Asian Studies, 6(2), 264-280. http://dx.doi.org /10.4232/10.ASEAS-6.2-3

Wibowo, A. S. (2012). Indonesian Migrant Workers: Foreign Exchange Heroes. Manpower Journal, 47:75-91. 